\title{
La poética de Pablo Trapero: impotencia, catábasis y corrosión de la ley
}

\section{Pablo Trapero's poetics: impotence, cathabasis and corrosion of the law}

\author{
Alfredo Dillon \\ Universidad Católica Argentina, Argentina \\ adillon@uca.edu.ar
}

\begin{abstract}
Resumen:
El objetivo de este artículo es analizar algunos rasgos de la poética de Pablo Trapero, uno de los directores más relevantes y prolíficos del cine argentino contemporáneo. Para eso se recorta un corpus de cuatro films -El bonaerense (2002), Leonera (2008), Carancho (2010) y El clan (2015)-, representativos de distintas etapas de su filmografía. El estudio apela a una perspectiva autoral, conciliándola con una lectura sociológica de los films. El análisis de la poética autoral de Trapero se despliega en función de tres ejes: la construcción de los personajes, la configuración diegética del hogar familiar y la emergencia de un diagnóstico sobre lo social signado por la corrosión de la ley y la normalización de la transgresión en la Argentina post crisis de 2001. El abordaje autoral aporta a la comprensión del llamado "Nuevo Cine Argentino" y del devenir industrial de algunos de sus representantes, entre quienes Trapero ocupa un lugar destacado.
\end{abstract}

\begin{abstract}
:
The aim of this article is to analyze some features of the poetics of Pablo Trapero, one of the most relevant and prolific directors of contemporary Argentine cinema. For this purpose, we have selected four films -El bonaerense (2002), Lion's Den (2008), Carancho (2010) and The Clan (2015) - that are representative of different stages of his filmography. The study appeals to an authorial perspective, as well as a sociological approach of the films. The analysis of Trapero's poetics is presented according to three axes: the construction of the characters, the figuration of family, and the emergence of a social outlook on Argentina post-crisis of 2001, marked by the corrosion of the law and the normalization of transgression. An authorial perspective contributes to the understanding of the so-called New Argentine Cinema and its industrial evolution: a phenomenon in which Trapero has played a fundamental role.
\end{abstract}

Palabras clave: Cine argentino; Trapero, Pablo; Autores; Nuevo Cine Argentino; análisis fílmico.

Keywords: Argentine cinema; Trapero, Pablo; Authors; New Argentine Cinema; Film analysis. 


\section{Introducción}

Pablo Trapero es una de las figuras centrales del cine argentino contemporáneo. El estreno de su ópera prima, Mundo grúa (1999), marca uno de los hitos fundacionales del Nuevo Cine Argentino (NCA), junto con Pizza, birra, faso (1997) de Adrián Caetano y Bruno Stagnaro. La filmografía de Trapero - una de las más prolíficas del cine argentino reciente, con nueve estrenos en veinte años- atravesó cambios importantes a medida que la industria cinematográfica nacional se fue consolidando. El objetivo de este artículo es analizar algunos rasgos de su poética, a partir de una selección de sus films.

Trapero -que firma sus películas como director, productor y guionista- ha reunido el favor de la crítica y los festivales con el interés del público (El clan tuvo más de 2 millones de espectadores, mientras que Elefante blanco y Carancho superaron los 600.000). La evolución de su filmografía traza claramente una parábola desde un cine independiente, de bajo presupuesto e influido por el neorrealismo italiano, hacia un cine más industrial.

Para dar cuenta de ese recorrido, en este artículo trabajaremos sobre cuatro films correspondientes a distintas etapas de su producción: El bonaerense (2002), representativa del momento inicial del NCA; Leonera (2008), que podría considerarse una película de transición hacia un modelo más industrial; y, finalmente, Carancho (2010) y El clan (2015), protagonizadas por actores de altísima popularidad como Ricardo Darín y Guillermo Francella, respectivamente. Los cuatro films comparten además un eje temático: sus historias giran en torno a la transgresión de la ley ${ }^{1}$. En estas películas se pone en juego la precariedad de la ley y su incapacidad para regular las vidas de los sujetos de manera justa. La policía, el sistema penitenciario, la justicia y la familia aparecen como instituciones asediadas por el fantasma de la desintegración social.

\footnotetext{
${ }^{1}$ El último film estrenado del director, La Quietud (2018), se enfoca en un universo familiar desde una mirada más intimista, retomando una línea presente en films previos como Familia rodante (2004) y Nacido y criado (2006).
} 


\section{El devenir del Nuevo Cine Argentino}

Pablo Trapero ha sido uno de los referentes más emblemáticas del denominado "Nuevo Cine Argentino" (NCA, según la sigla acuñada por la crítica), un movimiento ${ }^{2}$ de renovación cinematográfica en el que pueden inscribirse nombres tan heterogéneos como los de Lucrecia Martel, Adrián Caetano, Daniel Burman, Lisandro Alonso y Albertina Carri, entre otros. Aguilar sostiene que el NCA constituye un "nuevo régimen creativo” (2010, p. 13) anclado, por un lado, en la renovación de los modos de producción -por ejemplo, la aparición de la figura del director-productor, o la apelación al financiamiento de fundaciones extranjeras-; $y$, por el otro, en los cambios en la producción artística, derivados del impacto de las nuevas escuelas de cine (que mejoraron la formación del personal artístico y técnico), así como de los avances tecnológicos y de un cambio en la política de actores, que abrió la pantalla a caras desconocidas (2010, p. 22).

A más de veinte años del nacimiento del NCA y de la ópera prima fundacional de Trapero, el campo cinematográfico argentino se ha reconfigurado: "Los mayores exponentes del NCA se han contentado con asimilarse a la misma industria que los miraba en principio con desconfianza”, afirma por ejemplo Nicolás Prividera (2016, p. 47). La recuperación del país tras la crisis de 2001, el fortalecimiento de la industria y la consagración crítica del NCA permitieron a directores como Trapero -entre otros- pasar de estándares de producción independientes a trabajar en el marco de producciones de escala industrial, una vez que pudieron acceder a otros niveles de financiamiento.

La evolución del cine de Trapero también puede pensarse a partir de un uso progresivamente menor de la elipsis: las últimas películas resultan mucho más explicativas que las primeras. De todos modos, a través de la filmografía del director persisten al menos dos elementos que ya estaban presentes en su ópera prima. Por un lado, la exploración de los vínculos entre padres e hijos. Por el otro, la multiplicidad de roles desempeñados por el autor: en todas sus

\footnotetext{
${ }^{2}$ Verardi (2009) defiende la consideración del NCA como un movimiento a partir de una serie de rechazos comunes, reconocidos tanto por los cineastas como por la crítica: "Más allá de la innegable disparidad estética de los films, la idea de ruptura e introducción de un nuevo escenario en el universo de la cinematografía nacional aparece afirmada en el campo y consensuada por sus distintos exponentes" (2009, p. 181).
} 
películas, Trapero firma como director, guionista y productor (a través de su productora, Matanza Cine).

La categoría de director-productor es tal vez una de las principales innovaciones en los modos de producción introducidas por el NCA. Como plantea Hernán Musaluppi, la figura del "director productor" es emblemática de la primera etapa del NCA, signada por un “espíritu amateur”, cuya renovación fundamental tuvo que ver con "el modo de concebir y llevar adelante la producción (sin guion, sin dinero, sin previsión)” (2016, p. 101). En las últimas películas de Trapero -Elefante blanco, El clan y La Quietud- esa figura persiste, aunque las condiciones de producción han cambiado drásticamente: en las sucesivas películas, además de Matanza Cine y el INCAA, aparecen entre los productores el Instituto de la Cinematografía y de las Artes Audiovisuales (ICAA) de España, Televisión Española (TVE), El Deseo (de Pedro y Agustín Almodóvar), Patagonik, Kramer \& Sigman Films, Telefé y Sony.

Según la lectura de Aguilar (2010), la consolidación de directores como Trapero, Caetano o Diego Lerman como autores industriales constituye un momento de necesaria "institucionalización” del NCA, y marca una diferencia fundamental con la "frustrada" generación del 60. En este punto coinciden Aguilar y Prividera: el fracaso de la generación del 6o -el primer "Nuevo Cine Argentino"- impidió la conciliación entre autorismo e industria, que sí pudo materializarse a partir de la consolidación del NCA en las décadas de 2000 y 2010. Para Prividera (2018), films como El clan expresan un afán de "sellar la restauración del vínculo entre industria y autorismo que la dictadura vino a sepultar”.

\section{Metodología: la perspectiva autoral}

Concebir a un director de cine como autor implica sostener que su filmografía es portadora de cierta coherencia, que existen rasgos temáticos y estilísticos comunes a sus distintas películas: rasgos que, como marcas de identidad, las vuelven reconocibles como producidas por un mismo autor. En consecuencia, 
esta noción es correlativa de la posibilidad de concebir una poética transversal a varias obras 3 .

En este punto es necesario hacer tres aclaraciones. Primero: pensar a un director como autor no significa concebirlo como "autoridad" única sobre el texto fílmico ni, mucho menos, como única "fuente" de todas las decisiones estéticas plasmadas en el film. Segundo: tampoco supone desconocer que una película es el resultado de un trabajo colectivo. Tercero: la noción de autor no implica un interés (extra fílmico) en la biografía ni en la psicología del sujeto empírico, sino en las huellas fílmicas de una poética autoral.

El artículo se propone conciliar la perspectiva autoral con una mirada sociológica, sin descuidar la atención a la singularidad de cada película. Apelamos a la categoría de autor, pese a su mentada "muerte" a fines de los sesenta (Barthes, Foucault), seguida luego del "retorno del autor" (Burke, 1992) en el campo de los estudios literarios y culturales. Pese a los cuestionamientos posestructuralistas, en la práctica la noción de autor se ha sostenido tanto en la crítica como en la enseñanza de las artes, la literatura y el cine. Sí reconocemos, a partir de las ideas de Barthes, que el autor no debe ser considerado la autoridad máxima sobre una obra. Por eso, a los fines de nuestro trabajo, el análisis de los textos audiovisuales (el hecho fílmico) resulta más pertinente que otras metodologías, como las entrevistas a los realizadores, quienes pueden dar cuenta de sus intenciones, pero no ostentan una potestad particular en relación con los sentidos de su obra, abiertos a la lectura del espectador e independientes de la palabra de los autores.

La noción de autor fue introducida en la teoría y la crítica cinematográfica por la emblemática revista francesa Cahiers du cinéma, en la década de 1950, a partir de una reivindicación del "cine arte" europeo pero también de ciertos directores hollywoodenses como Hitchcock. Bazin hizo una conocida defensa de esta categoría: “La 'política de los autores' consiste, en resumidas cuentas, en elegir dentro de la creación artística el factor personal como criterio de

\footnotetext{
3 Uno de los pocos estudios sobre cine argentino reciente que recuperan explícitamente estas herramientas conceptuales es del Paulinelli (2005), titulado Poéticas en el cine argentino. 1995-2005. También la tesis doctoral de Verardi (2010) se estructura sobre la base de un criterio autoral.
} 
referencia, para después postular su permanencia e incluso su progreso de una obra a la siguiente" (2003, p. 101). España y Manetti (1999) señalan que los años 60 marcan el momento en que el auterismo irrumpe en el cine argentino, de la mano de la Generación del 60, y en simultáneo con otras cinematografías del mundo (Francia, Inglaterra, Estados Unidos, Brasil).

Para Bazin, la incorporación de la categoría de autor a la crítica cinematográfica marca la "adultez" del cine como arte, pero entraña un riesgo: que el autor se imponga sobre la obra e impida el análisis de la singularidad de cada película. En ese sentido, Bazin reivindica la política de los autores, pero rechaza el "culto estético de la personalidad" (2003, p. 103). A la vez, desde una concepción no individualista, aboga por la reconciliación de las nociones de autor y género, al afirmar que las convenciones no atentan contra la libertad creadora del director, sino que la fortalecen.

También Deleuze apela a la categoría de autor en sus estudios sobre cine, pero su uso de este concepto difiere de la concepción criticada por Barthes, para quien la noción de autor es un producto del individualismo moderno: alude a un individuo que precede al texto y lo funda (2009, p. 76). Aguilar afirma que en Deleuze el autor "ya no es un origen sino la fuerza que trata de desplegarse entre el automatismo de la imagen y la irreductibilidad del afuera" (2015, p. 28). Según Aguilar, "el estatuto autoral le permite [a Deleuze] sostener un régimen creativo contra la mercantilización y la espectacularización de la imagen" (2015, p. 26). En otras palabras, al igual que en los Cahiers -donde no todo director era digno de ser considerado autor-, en La imagenmovimiento y La imagen-tiempo el concepto de autor cinematográfico permitiría trazar una frontera entre cine artístico y cine comercial.

A continuación, nos proponemos estudiar la poética autoral de Pablo Trapero a partir de tres elementos recurrentes al interior del corpus seleccionado: ciertos rasgos en la construcción de los personajes, cierta gravitación de las configuraciones familiares sobre los sujetos y sobre el devenir narrativo, y cierto diagnóstico acerca de lo social signado por la corrosión de la ley y la normalización de la transgresión en la Argentina posterior a la crisis de 2001. La heterogeneidad del corpus, que incluye una película "basada en hechos 
reales" -El clan-, no es un obstáculo para el estudio de la poética autoral, puesto que el film es resultado de un proceso creativo (construcción de los personajes, de la tensión dramática y de la puesta en escena) análogo al de cualquier película ficcional.

\section{Los personajes: impotencia y catábasis}

El de Pablo Trapero es universo impiadoso, sin héroes, habitado por sujetos exhaustos y heridos, cuya capacidad de elegir ha sido pulverizada por el peso del fatalismo. Los personajes se ven inmersos en circunstancias que se les imponen con la contundencia de lo inexorable, y frente a las que nada pueden hacer. Los protagonistas de las películas seleccionadas aquí -El bonaerense, Leonera, Carancho y El clan- han visto prácticamente anulada su capacidad de agencia. Más bien transitan los vaivenes narrativos como arrastrados por el torrente de la fatalidad, sometidos al azar o a las voluntades de otros agentes más poderosos que ellos.

Zapa (El bonaerense), Julia (Leonera), Sosa (Carancho) y Alejandro (El clan) son personajes gobernados por fuerzas que los superan; carecen de soberanía sobre sus propias vidas. El contexto social y familiar los determina al punto de que les sustrae su capacidad individual de decisión.

Así es como Zapa (Jorge Román), en El bonaerense, ingresa a la policía por voluntad de su tío, sin quererlo, pero sin tampoco rehusarse, con la misma pasividad y obediencia con la que incurre en un delito -el robo de una caja fuerte- en el comienzo de la película. Zapa es el más pasivo de los personajes de Trapero: se trata de un sujeto apático ${ }^{4}$, cuya única decisión es la obediencia, y que pasa de un patrón a otro, incapaz de gobernarse a sí mismo.

En Leonera, el recorrido de Julia (interpretada por Martina Gusmán, pareja de Trapero, y productora y protagonista de buena parte de sus películas) también es ajeno a la voluntad de la protagonista: ella parece haber cometido

\footnotetext{
4 La apatía de los personajes en las primeras películas del NCA fue uno de los elementos más cuestionados por la crítica cinematográfica. El cuestionamiento se agudizó a partir de mediados de la década del 2000, cuando ese rasgo empezó a reiterarse y a volverse un lugar común en la construcción de los protagonistas (cfr. Porta Fouz, 2007).
} 
un crimen -el asesinato de su novio- que le resulta imposible recordar, y sobre el cual la película nunca ofrece una "versión oficial". Como consecuencia de ese homicidio elidido en la memoria de la joven -y en la narración cinematográfica, regida por su punto de vista-, Julia cae en la cárcel, donde ya no es capaz de organizar su rutina cotidiana, sino que debe adaptarse a las normas impuestas por la institución.

Sosa (Ricardo Darín), el protagonista de Carancho, es un abogado que ha perdido su matrícula y quiere salirse de la mafia de los "caranchos" (abogados que lucran con los accidentes de tránsito). Pese a sus intentos, una y otra vez vuelve a quedar entrampado en la red de corrupción -integrada también por policías y médicos- de la que resulta imposible evadirse por voluntad propia.

Finalmente, en El clan Trapero presenta la historia de Alejandro Puccio (Peter Lanzani) a partir de un esquema que ya había utilizado en películas anteriores: el del sujeto "inocente" que comete un delito bajo el influjo de otro personaje, su padre Arquímedes (Guillermo Francella). El vínculo entre Arquímedes y Alejandro define buena parte de la tensión dramática del film, cuyo punto de vista tiende a identificarse con el hijo - eje del conflicto ético- antes que con el padre -construido como un villano sin matices-. Los secuestros y su desenlace son conocidos por el espectador desde el comienzo, y por lo tanto el interés no se sostiene en función de qué pasará con las víctimas, sino con la relación de dominación entre padre e hijo.

Un rasgo recurrente en el cine de Trapero es la ambivalencia moral de sus protagonistas, en este caso cuatro sujetos que han quebrado la ley: Zapa, por medio del robo del comienzo de la película, pero también dentro de la policía, en su complicidad con las rutinas de corrupción; Julia, por medio del homicidio, aunque no queda del todo claro cuál ha sido su grado de participación en este; Sosa, por medio de la estafa a las víctimas de accidentes de tránsito, negocio que sostiene a "la Fundación", el estudio de abogados del que forma parte; Alejandro, a través de su iniciación en el "negocio" familiar, que involucra secuestrar a sus propios amigos 5 . Se trata, en todos los casos, de

\footnotetext{
5 En este sentido, hay que marcar como excepción la construcción de Arquímedes Puccio (Francella) en El clan: un villano casi arquetípico, con la mirada helada y la sonrisa inquietante.
} 
personajes ambiguos, con aspectos queribles y otros que pueden resultar incómodos para el espectador, como la falta de escrúpulos de Sosa, la indiferencia de Zapa o la excesiva obediencia de Alejandro. La ambigüedad se sostiene en sus acciones, pero también en el acceso limitado del espectador a la interioridad de estos sujetos.

En el transcurso de la narración, los protagonistas de Trapero se sumergen en mundos desconocidos para ellos. En ese proceso, atraviesan un aprendizaje (involuntario) que produce en ellos transformaciones internas, que a su vez se traducen en cambios físicos: cortes de pelo (en El bonaerense y Leonera), cambios de vestimenta (en Leonera), heridas y cicatrices (en las cuatro películas). Estas pequeñas metamorfosis marcan puntos de inflexión en la narración (como el ingreso de Zapa a la institución policial), o sirven también para marcar el paso del tiempo (en Leonera).

En Trapero, el Bildungsroman ${ }^{6}$ deja huellas visibles en el cuerpo. La progresión de esas marcas físicas es particularmente notoria en Carancho, donde Sosa y Luján van acumulando cicatrices y moretones hasta el "golpe" final, un choque que parece sellar su destino. Trapero explota la potencia del gesto; pone en escena rostros que condensan el contexto y hacen ingresar "el peso de lo real" (Dieleke, 2012, p. 176). El aprendizaje es aquí una experiencia de catábasis7, un proceso de descenso hacia el infierno: las trayectorias de los personajes conducen irremediablemente a la ruina. Ese movimiento hacia abajo es explícito en Carancho, donde se multiplican las imágenes de descenso en ascensores, escaleras y encuentros en espacios subterráneos.

Bonitzer señala que "el primer plano presenta, por definición, un objeto parcial, propicio, pues, tanto al fetichismo como a la fobia” (2007, p. 21). En

\footnotetext{
${ }^{6}$ El Bildungsroman o novela de aprendizaje es un género narrativo cuyos orígenes suelen remontarse a la novela Los años de aprendizaje de Wilhelm Meister de Goethe, publicada en 1796. Bajtín define este género como la representación de una "imagen del hombre en proceso de desarrollo" (2008, p. 209).

7 La catábasis es un concepto con larga tradición literaria: describe el proceso de descenso del protagonista al inframundo, en obras tan clásicas como la Odisea, la Eneida o la Divina Comedia. En la literatura moderna, también ha sido retomado por clásicos como Fiodor Dostoievski (Memorias del subsuelo), Albert Camus (La caída) y Samuel Beckett (autor, entre otras, de una obra titulada All That Fall). En los textos clásicos, la catábasis era un movimiento que precedía a la anábasis (ascenso), por medio del cual los protagonistas se consagraban como héroes (y, en el caso de Dante, se redimían). Para los personajes de Trapero, en cambio, este segundo movimiento aparece negado (la única excepción es Julia en Leonera).
} 
Trapero, el primer plano elude ambos polos para presentarse como una suerte de mapa en el que las líneas del rostro devienen huellas de la experiencia (violenta) de catábasis que han atravesado sus personajes. Parafraseando a Deleuze y Guattari (1989), podría leerse en estos films una suerte de rostrificación de la violencia social.

En estas películas de formación, la única pedagogía que funciona de manera efectiva es la violencia, presentada como un fenómeno normal de la vida social. Esa violencia se ve no solo en las acciones (choques, tiroteos, motines, secuestros, asesinatos, etcétera), sino también en los rostros. Trapero utiliza los primeros planos -ese elemento que, al explotar la fuerza de la mirada, distingue a la actuación cinematográfica de la teatral- para expresar las huellas de la violencia sobre sus personajes, en cuyas facciones pueden leerse los rastros del contexto hostil en que están inmersos.

En El clan, sin embargo, esa violencia aparece enmascarada por los rituales familiares que pretenden encubrirla. En el film abundan las escenas de "normalidad" familiar: vamos a los Puccio cenando, haciendo la tarea escolar con sus hijos, mirando la televisión, rezando en la mesa. Pero en la "casa del mal”, lo normal se vuelve siniestro y lo siniestro se normaliza: el film muestra a los miembros de la familia haciendo sus actividades cotidianas mientras se escuchan, de fondo, los gritos de los prisioneros.

\section{La desintegración familiar}

Pablo Trapero explora los universos familiares en varias de sus películas. La familia es el tema central de Familia rodante (2004), su film más inclinado hacia la comedia, mientras que la disgregación familiar, la pérdida y la culpa constituyen el núcleo del argumento en Nacido y criado (2006) y en La Quietud (2018), donde se incorpora también la cuestión del incesto. Ya su ópera prima, Mundo grúa (1999), hacía foco en el vínculo padre-hijo, retomado en El clan, mientras que el eje de Leonera es la maternidad. En El bonaerense y Carancho, en cambio, lo familiar no resulta central, pero sí se introduce una historia de amor que alivia la sordidez del entorno.

En El bonaerense, Mabel (Mimí Ardú) representa para Zapa la única posibilidad de salvarse de la lógica corrupta de la policía, pero esa salvación no 
se concreta. En Carancho, la relación amorosa de Sosa (abogado cínico y experimentado) y Luján (la joven médica recién llegada del interior) se entreteje sobre el trasfondo urgente de los accidentes nocturnos y las salas de emergencias. En Leonera -la única de las cuatro películas del corpus que brinda una salida a la protagonista-, Julia se acerca a Marta (Laura García) y termina formando con ella una familia ensamblada durante el encierro: frente la hostilidad y la despersonalización de la cárcel, Julia encuentra en su compañera un espacio para el afecto y la intimidad.

En El clan, en cambio, la trama amorosa -entre Alejandro y su novia Mónica (Stefanía Koessl) - no llega a desplegarse, sino que queda en la superficie, apenas esbozada en un par de escenas. Mónica quiere irse: sueña con instalarse en Suecia. Sin embargo, ese romance y el deseo de emigrar terminan proveyendo no una posibilidad de fuga y redención, sino una motivación que contribuye a explicar el hundimiento de Alejandro: para irse a Suecia, necesitan dinero. En El clan, la única fuga posible es el salto al vacío del final, y aun ese intento resulta frustrado: Alejandro sobrevive -según se nos informa en las placas que cierran la película, tratará de suicidarse varias veces más, pero fallará siempre-.

Aquí las mujeres -Mabel, Luján, Marta, Mónica- ofrecen un refugio para la violencia. En El bonaerense y Carancho, los personajes femeninos encarnan la moral, poseen una suerte de potencial redentor para los personajes masculinos. Funciona en estas películas el rol que les atribuye Mongin a los personajes femeninos en ciertos films de acción: "Las mujeres, cuando no sucumben a la fascinación de la violencia, cuando no quieren ocupar violentamente el lugar de los hombres violentos, son casi siempre el instrumento de una regeneración” (1999, p. 50). Las mujeres representan, entonces, una posible salida a la violencia, pero esa posibilidad no se consumará en estos films, donde la brutalidad del entorno termina imponiéndose.

Por ausencia o por exceso, la configuración del hogar familiar resulta fundamental en la construcción de los personajes y de la tensión narrativa. En El bonaerense y Carancho, vemos a los personajes en sus departamentos, pero esos planos subrayan la ausencia de hogar: los protagonistas viven solos y 
únicamente vuelven a sus casas para recuperar energías. Si en el cine argentino la mesa ha sido el espacio privilegiado a partir del cual presentar a la familia (Turquet y Pérez Rial, 2009) ${ }^{8}$, en estas películas vemos a los personajes comer solos y sin mesa: en el colchón tirado en el piso (Zapa), o en un sillón frente al televisor (Sosa).

Los films de Trapero parecen decir que en la ciudad no hay hogar posible: la casa funciona apenas como un lugar adonde volver a descansar de la hostilidad del mundo -no casualmente los films de Trapero transcurren en La Matanza, en buena medida una gran ciudad-dormitorio al lado de Buenos Aires-. Los protagonistas están solos en el laberinto urbano, desprovistos de redes de apoyo: la familia de Zapa ha quedado en su pueblo; Julia fue abandonada por su madre y su padre ha muerto; Sosa no tiene familia y la de Luján también está lejos. Este aislamiento puede ser leído en clave política, en relación con los procesos de individualización (Beck, 1998; Bauman, 2010) definidos por las transformaciones sociales neoliberales.

Una vez más, en este punto El clan funciona de manera diferente. Aquí una de las principales innovaciones con respecto a los films anteriores tiene que ver con el espacio -geográfico y social- elegido por el director: la historia ya no transcurre en La Matanza ni en los márgenes del conurbano bonaerense empobrecido, sino en el barrio acomodado de San Isidro, territorio de la clase alta y media alta. Ese desplazamiento espacial es correlativo de una configuración diferente del hogar familiar, presentado aquí como un espacio cerrado y siniestro.

La cámara se ocupa de presentar la casa Puccio con precisión, y se detiene particularmente en los elementos más emblemáticos: el portón que separa el interior del exterior, la escalera caracol que sube al primer piso desde el patio, el sótano (que, junto con el baño de la primera planta, es el espacio donde son retenidos los prisioneros). El montaje señala la contigüidad entre el hogar y el negocio familiar (primero rotisería, luego tienda de surf). Esa proximidad se enfatiza en varias escenas: por ejemplo, en un plano secuencia vemos a

\footnotetext{
8 Sobre el vínculo entre mesa y familia en el cine argentino, Turquet y Pérez Rial señalan: "Históricamente, una vasta producción de cine de ficción centró sus temáticas en la familia, con la casa como uno de sus escenarios privilegiados y, más específicamente, la mesa como esa suerte de altar profano y lugar de comunión" (2009, s/p).
} 
Alejandro cerrando su local y luego abriendo el portón para que ingrese el auto, que lleva una víctima en el baúl. La vecindad de casa y negocio funciona como una metáfora espacial de la historia que se está contando: el verdadero "negocio" de los Puccio -el secuestro de empresarios- literalmente tiene lugar dentro del hogar familiar.

Dentro de la casa, la escalera separa (o une) los espacios de la normalidad familiar y el horror. Uno de los momentos más emblemáticos del film es el plano secuencia que exhibe la continuidad de ambos mundos: Arquímedes conversa con su esposa, sube desde la cocina con una bandeja de comida, habla de banalidades con los hijos; a medida que sube la escalera, se deja de escuchar el sonido de la actividad familiar cotidiana e irrumpe una sucesión de golpes secos; finalmente, Arquímedes entra al baño donde está encerrada la primera víctima. En su crítica del film, Miccio propone leer este travelling en relación con las reflexiones de Hannah Arendt: "Existe una continuidad entre las acciones cotidianas y las acciones extraordinarias que exige ser rotulada como banalidad del mal [...] Arquímedes y su esposa sostienen la normalidad monstruosa a la que apunta Trapero" (Miccio, 2015, s/p).

El amor representa, en estas películas, la promesa de la felicidad: una línea de fuga, un refugio en medio de la intemperie y el derrumbe que rodea a los personajes. Sin embargo, esa posibilidad de redención que encarnan las mujeres en El bonaerense, Carancho y El clan resultará frustrada. Los protagonistas masculinos no logran escapar de las estructuras en las que han quedado atrapados, y que los arrastran hacia una violencia creciente.

Signados por el declive físico y moral de los personajes, el único de los cuatro films cuyo final esboza una esperanza es Leonera. La huida de la protagonista con su hijo permite vislumbrar un futuro diferente, condensado en el plano de perfil de los dos personajes mirando hacia adelante, contemplando la otra orilla -que el espectador verá recién en los planos siguientes-. El territorio extranjero (Paraguay) aparece aquí como una zona de libertad, al margen del peso de la ley que ha caído sobre Julia de manera tan aplastante como absurda. Agobiados por una realidad hostil, los personajes de Trapero viven planeando su escape (Sosa quiere abandonar la "Fundación"; Zapa quiere "el traslado" a su pueblo de origen; Julia quiere reunirse con su hijo; Alejandro junta dinero 
para irse del país con su novia). La fuga en estas películas aparece cargada de un valor utópico: cuando la realidad es infernal, huir significa salvarse. Únicamente Julia logra concretar esta huida utópica, de la mano de su hijo pequeño, encarnación del futuro. Sosa, Zapa y Alejandro, en cambio, quedan fatalmente atrapados en la espiral de violencia.

\section{La corrosión de la ley}

Las cuatro películas construyen un presente signado por la corrosión de la ley. En El bonaerense, el asunto central es la corrupción de una policía enmarañada en casos de gatillo fácil y complicidad con todo tipo de organizaciones delictivas. En Leonera se aborda la situación de las mujeres que son madres en la cárcel. En Carancho el tema son los accidentes de tránsito, cuya magnitud es presentada por medio de una placa inicial que informa la cantidad de muertes por esta causa en la Argentina, produciendo un "efecto documentalizante" (Hortiguera, 2012, p. 118). En El clan, las prácticas delictivas de los Puccio -directamente vinculadas con la represión ilegal durante la última dictadura cívico-militar- son presentadas como un "negocio" familiar.

Las cuatro películas seleccionadas abordan desde diferentes puntos de vista los policías, las presas, los abogados, los criminales- el problema de la legalidad. Los films coinciden en señalar el absurdo de la ley y su incapacidad para regular de manera justa las relaciones sociales, así como el estrecho vínculo entre Estado y transgresión.

En El bonaerense, Zapa comete un delito (la violación de la caja fuerte) sin querer, mandado por su patrón, quien le presenta como un trabajo de cerrajería lo que en realidad es un robo. Paradójicamente, es ese delito lo que motiva su ingreso a la policía bonaerense: Zapa se vuelve un representante de la ley precisamente por haberla violado. A lo largo de la película, el protagonista ascenderá dentro de la estructura policial por medio del delito: quedará involucrado en las rondas de recaudación de coimas callejeras, que lo obligan a visitar a prostitutas, dueños de locales de juego y desarmaderos de autos, con quienes la policía mantiene pactos y zonas liberadas. 
En Leonera, la ley castiga a la protagonista, aunque el espectador no llega a saber cuál ha sido su participación en el homicidio que se le imputa. La narración escatima información y el asesinato no llega a desentrañarse nunca, lo que bloquea la posibilidad de llegar a una solución justa: sin verdad no puede haber justicia. Julia ensaya su declaración judicial como si se tratara de un monólogo teatral: “Te lo tenés que creer”, le dice su abogado, priorizando la verosimilitud sobre la verdad.

En Carancho, la aplicación de la ley es un ejercicio cínico, un negocio que permite aprovecharse simultáneamente de las personas más vulnerables -las víctimas sin recursos de los accidentes de tránsito- y de las aseguradoras. Como en El bonaerense, la película muestra que la corrupción nunca es un asunto individual, sino que funciona en red, en este caso entrelazando a representantes de la ley -abogados y policías- en asociación ilícita. La trama corrupta involucra también a los hospitales públicos y al servicio de emergencias; todos son, en alguna medida, "caranchos".

La corrosión de la ley produce distorsiones en el lenguaje de estos personajes: no hay una verdad que permita hacer justicia, ni un significado que sostenga el valor de las palabras. En El bonaerense, el verbo arreglar alude siempre a una intervención contraria a lo que manda la ley: "Ya se va a arreglar todo", le dice a Zapa el comisario de su pueblo, cuando el tío del protagonista ya ha intervenido para salvarlo del castigo y hacerlo ingresar a la policía. "Estás pasado. Pero te lo voy a arreglar”, le dice una oficial a Zapa cuando revela su edad. En esta película, arreglar significa saltarse la ley, pasarla por alto; paradójicamente, el sujeto de esa acción siempre es un representante de la ley. Otro eufemismo es el que denomina, en Carancho, al estudio de abogados corruptos: la "Fundación”. Cargada de ironía, la palabra invierte el sentido del trabajo de estos caranchos; presenta como asistencia lo que en realidad es estafa. En definitiva, el vaciamiento de la ley permite prescindir del compromiso entre las palabras y las cosas; el lenguaje se revela tramposo.

Por su parte, El clan presenta la actividad de los Puccio como un elemento que traza una continuidad entre la etapa de la dictadura cívico-militar y la primavera democrática: la única diferencia es que, caída la dictadura, el negocio se privatiza y Arquímedes ya no secuestra para el Estado, sino en 
beneficio propio. El film marca la conexión de Arquímedes con el poder militar, pero ese lazo resulta invertido en el discurso del protagonista, quien se presenta por teléfono como parte de un grupo guerrillero. En este sentido, la película también exhibe un vaciamiento del lenguaje (en este caso, del discurso político): Puccio utiliza nombres de organizaciones armadas de izquierda, pero perteneció a la Triple A; en una escena se afirma por ejemplo que los jugadores de rugby de Los Pumas son "los verdaderos héroes" nacionales (en vez de los combatientes de la Guerra de Malvinas).

Los Puccio funcionan como una metonimia de los actores sociales que se enriquecieron con la dictadura, es decir, que encontraron en el gobierno militar una oportunidad de negocio mientras las grandes mayorías sufrían empobrecimiento y represión. El enriquecimiento de esos actores -ciertas familias, corporaciones nacionales y multinacionales- constituye otro factor de continuidad entre dictadura y democracia: todos ellos persisten, a más de cuarenta años del golpe, entre los principales agentes de poder de la democracia9.

Delito y ley, crimen y autoridad se han vuelto indiscernibles en los mundos que retratan estas películas. Carcomidas por dentro, atrapadas en redes de complicidades oscuras, en el cine de Trapero las instituciones -la policía, el sistema penitenciario, la justicia, la familia, la salud pública- parecen al borde del colapso. La burocracia estatal es presentada como un conjunto de rituales despersonalizados y automáticos.

Estos rituales burocráticos son registrados con especial minuciosidad en Leonera, donde hasta los niños resultan objeto de los procesos de requisa, en los que una y otra vez se repiten las mismas preguntas y hasta lo más personal -el nombre propio- se invierte ("Julia Zárate" pasa a ser "Zárate, Julia"). La burocracia se representa también, en El bonaerense, por medio de la absoluta dependencia de los "papeles" y los "documentos", y a través del culto a las insignias y jerarquías: tan importante como obtener un ascenso es portar las enseñas que lo certifican, para hacer valer el nuevo cargo ante los demás.

\footnotetext{
9 El planteo de El clan será retomado por Trapero en La Quietud, aunque con dos diferencias: en esta última, el universo corresponde al de la clase alta argentina -y no al de la clase media con pretensiones aristocráticas-, y la familia se configura a partir de la figura dominante de la madre (Graciela Borges) y no del padre.
} 
La decadencia de las instituciones estatales se ve reflejada en su precariedad material. En El bonaerense, a la policía no le andan los vehículos, las armas "reglamentarias" que reciben los oficiales no sirven, el sueldo se cobra tarde. En Carancho, el hospital público está colapsado por la violencia social y por el ritmo inhumano de trabajo de los médicos; se ve basura en los pasillos y el edificio está deteriorado. Todos estos signos revelan el desmoronamiento del sistema de salud estatal. También en Leonera las oficinas judiciales por donde circula Julia se ven sucias y descuidadas.

La corrosión de la ley deja el terreno libre para el individualismo y el oportunismo, que alcanza su máxima expresión en Carancho y en El clan. En un mundo sin ley y sin instituciones sólidas, lo único que les queda a los personajes es la confianza interpersonal: la clave para sobrevivir es elegir bien de quién fiarse (el destino de Zapa, por ejemplo, se resuelve gracias a sus contactos: primero el tío, luego el comisario). En ese sentido, como en el código mafioso, "lo primero es la familia" (parafraseando el eslogan de $L a$ familia Benvenuto, otra ficción familiar protagonizada por Guillermo Francella en los años noventa).

De todas maneras, las narraciones muestran que la confianza sostenida en vínculos afectivos resulta demasiado endeble: Zapa es traicionado por el Polaco (al principio) y por Gallo (al final); en Carancho, Sosa también traiciona y es traicionado; en El clan, los Puccio son capturados y Alejandro no logra escapar del influjo de su padre. Frente a la caída de la ley, lo único que queda es el afecto privado, sostenido sobre pactos provisorios y precarios, siempre a punto de quebrarse.

\section{Conclusiones}

El análisis del corpus sugiere que la adopción de condiciones de producción industriales no supone necesariamente la ausencia o el abandono de un discurso autoral. Lo mismo puede decirse con respecto al recorrido exitoso de una película en el mercado: frente al prejuicio -aún vigente en la academia, y en particular en los estudios sobre cine argentino reciente- de que el cine "comercial" no merece ser analizado en los mismos términos que el cine "de autor”, el análisis del corpus fílmico permite reconocer la persistencia de 
ciertos elementos que configuran la poética de Pablo Trapero (o, más bien, una zona de su poética, puesto que el artículo deja de lado una parte de su filmografía en la que emergen también otras preocupaciones).

El recorrido por la poética de Trapero se enfoca en un cierto modo de construcción de los personajes, presentados a partir de una concepción fatalista que les impide avanzar en la consecución de cualquier proyecto personal: son sujetos impotentes, movidos por fuerzas superiores a ellos mismos que los arrastran en una trayectoria descendente (catábasis). Otro elemento analizado es la gravitación de las configuraciones familiares sobre los sujetos y sobre el devenir narrativo: la ausencia de hogar (en El bonaerense y Carancho), o la presencia de un hogar monstruoso (en El clan) definen la situación de los personajes; las tramas incorporan una historia de amor que promete un camino de redención para el protagonista, pero esa redención siempre resulta frustrada.

En tercer lugar, la poética de Trapero puede pensarse a partir de un determinado diagnóstico sobre lo social, signado por la corrosión de la ley y la normalización de la transgresión. Abordar el hecho fílmico desde el punto de vista estético requiere también observar el modo en que el film dialoga con el contexto social: en el caso de Trapero, ese contexto remite a la Argentina posterior a la crisis de 2001 (visible ya en Mundo grúa, protagonizada por un desempleado). En estas películas el presente social es leído desde una perspectiva pesimista y, en el caso de El clan y La Quietud -los films más recientes-, en continuidad con el horror de la dictadura.

En definitiva, el abordaje autoral permite comprender ciertos movimientos o rasgos epocales de una cinematografía -en este caso, el Nuevo Cine Argentino y su devenir- a partir de las poéticas que emergen en un determinado contexto histórico. Se trata de un modo de abordaje que articula la mirada estética con la lectura sociológica. Además, es una metodología que requiere interpretar cada film en el marco de una filmografía más amplia, y que, para el caso específico de Pablo Trapero, contribuye a la comprensión de la obra de uno de los directores más relevantes del cine argentino contemporáneo. 


\section{Referencias bibliográficas}

Aguilar, G. (2010). Otros mundos. Un ensayo sobre el nuevo cine argentino. Buenos Aires: Santiago Arcos.

Aguilar, G. (2015). Más allá del pueblo. Imágenes, indicios y políticas del cine. Buenos Aires: Fondo de Cultura Económica.

Bajtín, M. (2008). Estética de la creación verbal. Buenos Aires: Siglo XXI.

Barthes, R. (2009). El susurro del lenguaje. Barcelona: Paidós.

Bauman, Z. (2010). Mundo consumo. Ética del individuo en la aldea global. Buenos Aires: Paidós.

Bazin, A. (2003). "De la política de los autores". En Baecque, A. (comp.) La política de los autores. Manifiestos de una generación de cinéfilos. Barcelona: Paidós.

Beck, U. (1998). La sociedad del riesgo. Hacia una nueva modernidad. Barcelona: Paidós.

Bonitzer, P. (2007). El campo ciego. Ensayos sobre el realismo en el cine. Buenos Aires: Santiago Arcos.

Burke, Sean (1992). The Death and Return of the Author: Criticism and Subjectivity in Barthes, Foucault and Derrida. Edimburgo: Edinburgh University Press.

Deleuze, G. y Guattari, F. (1989). Mil mesetas. Capitalismo y esquizofrenia. Valencia: Pre-Textos.

Dieleke, E. (2012). “Lo real' en suspenso: narrativas excepcionales de la Argentina reciente". En Cuadernos de Literatura, $\mathrm{N}^{\circ} 32$, juliodiciembre, pp. 155-185.

España, C. y Manetti, R. (1999). "El cine argentino, una estética comunicacional: de la fractura a la síntesis”. En Burucúa, J. E. (dir.). Nueva Historia Argentina. Arte, sociedad y política. Buenos Aires: Sudamericana.

Hortiguera, H. (2012). "Después de la globalización, la destrucción de lo social en dos filmes argentinos: Las viudas de los jueves y Carancho". En Letras Hispanas, vol. 8.1, primavera, pp. 112-127.

Miccio, J. (2015). "De regreso: El clan". En Hacerse la Crítica. En línea: https://www.hacerselacritica.com/de-regreso-el-clan-por-jose-miccio/

Mongin, O. (1999). Violencia y cine contemporáneo. Ensayo sobre ética e imagen. Barcelona: Paidós.

Musaluppi, H. (2016). "Tensiones. (Veinticinco años de Nuevo Cine Argentino)". En Revista de Cine, No $^{\circ}$, pp. 99-107, Universidad del Cine.

Paulinelli, M. (coord.) (2005). Poéticas en el cine argentino. 1995-2005. Córdoba: Comunicarte. 
Porta Fouz, J. (2007). "Genealogías: sobre críticos y personajes argentinos". En El Amante, $\mathrm{N}^{\mathrm{o}} 181$, junio. En línea: www.otroscines.com/nota?idnota $=331$

Prividera, N. (2016). El país del cine. Para una historia política del nuevo cine argentino. Córdoba: Los Ríos.

Prividera, N. (2018). "Un muchacho como yo. A propósito de El ángel". En Con los ojos abiertos, 21/08/2018. En línea: www.conlosojosabiertos.com/inconformista-02-la-colulmna-nicolasprividera-muchacho-proposito-angel//

Turquet, M. y Pérez Rial, A. (2009). "Figuraciones de un espacio con historia. La mesa y su inserción en el relato del cotidiano familiar en el cine argentino de 1995-2005”. En Figuraciones, No 6, diciembre. En línea: http://revistafiguraciones.com.ar/numeroactual/articulo.php?ida $=137$ \&idn=6\&arch

Verardi, M. (2009). "El Nuevo Cine Argentino: claves de lectura de una época". En Amatriain, I. (coord.): Una década de nuevo cine argentino (19952005). Industria, crítica, formación, estéticas, pp. 171-189. Buenos Aires: CICCUS.

Verardi, M. (2010). Nuevo cine argentino (1998-20o8): formas de una época. Tesis doctoral, Facultad de Filosofía y Letras, Universidad de Buenos Aires. 